УДК 342.98:174

DOI https://doi.org/10.51989/NUL.2021.4.16

\title{
ПРОФЕСІЙНА ЕТИКА ДЕРЖАВНИХ СЛУЖБОВЦІВ: ПОНЯТТЯ, ОСОБЛИВОСТI
}

\author{
Серих Олена Василівна, \\ orcid.org/0000-0002-4222-7217 \\ кандидат юридичних наук, \\ доцент кафедри державно-правових дисциплін \\ Міжнародного гуманітарного університету
}

Статтю присвячено дослідженню понять, особливостей професійної етики державних службовців. Державна служба як специфічний вид публічної служби має особливості етичних норм, яких мають дотримуватися державні службовці під час виконання своїх професійних обов'язків. Відсутність єдиного підходу щодо доктринального визначення поняття «професійна етика державного службовця» також зумовлює актуальність дослідження. Проаналізовані різні визначення поняття професійної етики державних службовців. Професійна мораль державних службовців - це особливості моральної свідомості, поведінки державних службовців, взаємовідносин з іншими особами, які зумовлені державно-службовою діяльністю.

Акцентується увага на тому, що визначення морально-етичних засад поведінки державних службовців неможливо без урахування особливостей державної служби та місця державного службовця в суспільній діяльності. Державні службовці мають особливе суспільне призначення, цілі, завдання, які зумовлені особливостями їхньої професійної діяльності. 3'ясовано, що існують особливості діяльності державних службовців у залежності від їх видів. Відповідно до видових і родових класифікацій виділяються етичні стандарти поведінки залежно від галузі проходження державної служби.

Зроблено висновок, що державні службовці в професійній діяльності потенційно мають конфлікти, складні ситуації, корупційні ризики, що вимагає наявності не лише професійних (ділових), психологічних якостей, освітнього рівня, а й моральних якостей. Під час виконання своїх посадових обов'язків державні службовці мають усвідомлювати, що вони зобов'язані вірно служити народові України й гідно нести звання державного службовця.

Запропоновано під професійною етикою державних службовців розуміти систему моральних і правових вимог, принципів, яких повинні дотримуватися державні службовці під час виконання завдань і функцій держави на професійній основі. Професійна етика окремих груп державних службовців відображує видові та родові особливості державної служби, що має бути враховано у відповідних нормативно закріплених правилах етичної поведінки державного службовця та під час розроблення теоретичних положень етики професійних груп державних службовців.

Ключові слова: державна служба, державний службовець, етика, мораль, професійна етика, професійна етика державних службовців.

\section{Sierykh Olena. Professional ethics of civil servants: concepts, peculiarity}

The article is devoted to the study of concepts, features of professional ethics of civil servants. Civil service as a specific type of public service has peculiarities of ethical norms that civil servants must adhere to in the performance of their professional duties. The lack of a unified approach to the doctrinal definition of the term "professional ethics of a civil servant" also determines the relevance of the study. Different definitions of the concept of professional ethics of civil servants are analyzed. Professional morality of civil servants is the features of moral consciousness, behavior of civil servants, relationships with other persons, which are due to civil service activities.

Emphasis is placed on the fact that the definition of moral and ethical principles of behavior of civil servants is impossible without taking into account the peculiarities of the civil service and the place of the civil servant in public activities. Civil servants have a special social purpose, goals, objectives, which are due to the peculiarities of their professional activities. It was found that there are features of the activities of civil servants depends on their types. According to species and genus classifications, ethical standards of conduct are distinguished depends on the field of civil service. 
It is concluded that civil servants in their professions have the potential conflicts, difficult situations, corruption risks, which requires not only professional (business), psychological qualities, educational level, but also moral qualities. In the performance of their duties civil servants must be aware that they are obliged to serve the people of Ukraine faithfully and to carry the title of civil servant with dignity.

It is proposed to understand the professional ethics of civil servants as a system of moral and legal requirements, principles that must be followed by civil servants in performing the tasks and functions of the state on a professional basis. Professional ethics of certain groups of civil servants reflects the specific and generic peculiarity of the civil service, which should be taken into account in the relevant regulations of ethical conduct of civil servants and in developing theoretical provisions of ethics of professional groups of civil servants.

Key words: civil service, civil servant, ethics, morality, professional ethics, professional ethics of civil servants.

Постановка проблеми. Складовою частиною загальної моралі суспільства $\epsilon$ морально-професійні норми, які відображують специфічний характер професійної діяльності. 3 моменту перших досліджень моральних аспектів людської діяльності від стародавніх часів і дотепер професійна мораль набула більш чіткого оформлення, що й призвело до виникнення професійної етики та затвердження її основ на рівні нормативно-правових актів. У професійній моралі відбиваються особливості моральної свідомості, взаємовідносин, поведінки людей, які зумовлені специфікою професійної діяльності. Державна служба як специфічний вид публічної служби має особливості щодо етичних норм, яких мають дотримуватися державні службовці під час виконання завдань і функцій держави.

У наукових джерелах щодо професійної етики державних (публічних службовців) вживаються такі поняття, як: «адміністративна етика», «службова етика», «етика поведінки державного службовця», «професійна етика публічних службовців», «професійна мораль державних службовців», «етика державного службовця», «етика державної служби». Відсутність єдиного підходу щодо доктринального визначення поняття професійної етики державного службовця також зумовлює актуальність дослідження.

Аналіз останніх досліджень і публікацій. Проблемами професійної етики, дослідженням її специфіки в окремих видах професійної діяльності займалися такі вчені, як: Т.Г. Аболіна, О.М. Бандурка, В.П. Бралатан, А.Б. Войтенко, Г.В. Гребеньков, Л.В. Гуцаленко, О.І. Денищик, С.Д. Дубенко, Н.Г. Здирко, Б.К. Левківський, В.О. Лозовой, К.Ф. Луганський,
В.А. Малахов, В.I. Мельниченко, Н.Р. Нижник, О.В. Петришин, Н.С. Пугачова, Д.П. Фіолевський, I.I. Чернокозов, В.Н. Чернокозова та інші.

Проблемам професійної етики публічних (державних) службовців присвятили свої праці Ю.П. Битяк, Т.Е. Василевська, Ю.С. Даниленко, Н.В. Янюк, I.I. Яремін та інші вчені. Професійну етику суддів досліджували С. Жуков, А. Музиченко, Ю. Меліхова, О. Овсяннікова, І.І. Припхан тощо. До питань професійної етики прокурорів зверталися В.О. Алексєєва, I.O. Билиця, О.М. Осадца, С. Петров, О. Толочко, О.О. Шандула та ін. Однак на даному етапі розвитку державної служби у світлі євроінтеграційних процесів норми, які відображають особливості професійної етики державного службовця, потребують більш детального аналізу на рівні системного дослідження, оскільки державний службовець як представник держави повинен бути взірцем чесності, порядності, доброзичливості, справедливості.

Тому метою статті $\epsilon$ визначення поняття професійної етики державного службовця та з'ясування ії особливостей.

Виклад основних положень. Частиною загальної науки етики $є$ професійна етика, об'єктом вивчення якої $\epsilon$ «специфічні, морально-професійні норми, стосунки, а також норми, принципи, заповіді пануючої в суспільстві моралі, трансформовані до особливостей того чи іншого виду професійної діяльності, що регулюють поведінку професіоналів під час виконання ними функціональних обов'язків, санкціонованих громадською думою й особистими переконаннями професіоналів» [10, с. 201]. У професійній етиці фіксуються вже не стихійно сформовані 
моральні норми, а інституційні, свідомо сформовані професійно-етичні встановлення. Придбання професійною етикою інституціонального характеру свідчить про заміну спонтанних дій на передбачувану, очікувану, модельовану та регульовану поведінку [15, с. 7].

Кожна трудова діяльність (незалежно від професії) базується на моральній системі суспільства. Очевидно, що в «ії лоні можуть обґрунтовуватися особливі моральні норми, що відбивають специфіку професійної діяльності» [10, с. 197]. Представники будь-якої професії мають своє суспільне призначення, свої цілі, всередині кожної професійної групи складаються певні специфічні зв'язки і стосунки людей. У кожній професії можуть мати місце «свої» типові ситуації, конфлікти, труднощі й небезпеки, які характеризують відносну самостійність професії та у свою чергу вимагають від людини певної професії специфічного набору якостей (психологічних реакцій, емоційної стійкості тощо) як професіональних (ділових), так і моральних.

Виокремлення особливих професійноетичних встановлень, в яких загальнолюдські принципи моралі конкретизуються стосовно професійної діяльності, зумовлено низкою факторів: своєрідністю місця та діяльності професійного колективу в суспільстві; специфікою міжособистісних відносин у професійній групі людей; підвищеними моральними вимогами, особливою напруженістю, складністю реалізації етичних норм у певних професіях $[15$, с. 7]. Перелічені умови мають визначальне значення для професійної діяльності державних службовців.

Професійна етика вирізняється: усвідомленою ретельною розробкою професійних етичних норм; побудовою системи взаємозалежних цінностей, принципів, норм, установок, зафіксованих в Етичному кодексі; існуванням групи людей, що відповідають за підтримку і захист цих норм $[15$, с. 7].

Зазвичай термін «професійна етика» вживається для позначення своєрідного етичного кодексу людей певної професії, певного соціального угрупування, тобто поняття «професійна етика» і «етичний кодекс» ототожнюються.
А. Музиченко слушно зауважує, що професійна етика $\epsilon$ збірним поняттям, вона охоплює весь спектр професійних відгалужень етики: медичної, юридичної, педагогічної тощо [14, с. 84]. Професійна етика - сформована система конкретних моральних норм із супутніми їм практичними правилами, які «обслуговують» ту чи іншу галузь людської діяльності [16]. Г.Л. Чайка зазначає, що професійна етика - це конкретно визначений набір моральних норм, який слугує керівництвом поведінки в тій чи іншій професійній діяльності [20].

Отже, все це зумовлює специфіку морально-етичних норм поведінки представників різних професій (професійних груп), у тому числі державних службовців.

Г.В. Котович розглядає етику державних службовців та посадових осіб органу місцевого самоврядування як результат професійної діяльності з огляду на ціннісні орієнтири суспільства. Також етику можна розглядати через цілі, завдання, мотиви, засоби, дії, які використовують службовці для досягнення поставленої мети. На її думку, професійна етика державного службовця допомагає конкретизувати, реалізувати моральні цінності в умовах, часом вельми складних, незвичайних. Професійна етика державного службовця це система норм поведінки, порядок дій і правил, взаємин і принципів державнослужбових відносин, що є сукупністю найбільш придатних, глибоко усвідомлених і конкретизованих норм загальнолюдської моралі, які властиві конкретному суспільству [12, с. 6]. Схоже визначення формулюють інші вчені (А.Б. Войтенко, В.П. Якобчук, Н.С. Пугачова), які зауважують, що етика державного службовця це система придатних і глибоко усвідомлених норм поведінки, певний порядок дій, правил взаємин і принципів державнослужбових відносин, що належать даному суспільству і $€$ нормами загальнолюдської моралі. Професіоналізм і ефективність роботи державного службовця - це показник його моральності, вірності своєму професійному обов'язку [7].

H.I. Требенець зазначає, що професійна етика публічних службовців - сукупність моральних правил поведінки публічних службовців, за допомогою яких можна 
оцінити їхню діяльність із точки зору таких цінностей, як справедливість, доброчесність, сумлінність, гідність, лояльність, чуйність, толерантність, відповідальність, професіоналізм тощо [19].

I.I. Яремин пропонує визначення поняття «службова етика», яке $\epsilon$ найширшим поняттям у сфері професійної етики. Це сукупність найбільш загальних норм, правил, принципів поведінки людини у сфері її професійної та службової діяльності. Етикет службових взаємин - це сукупність найбільш доцільних правил поведінки людей у трудових колективах, зумовлених найважливішими принципами загальнолюдської моралі й моральності. Під правилами службової поведінки вчений розуміє норми належної службової поведінки, що забезпечують добропорядне виконання службових обов'язків і дотримання встановлених обмежень на основі співвідношення службової поведінки із загальноприйнятими етичними нормами [22, с. 17].

В.П. Мельников під адміністративною етикою розуміє адаптовані до практичних потреб державної і муніципальної служби відомості про основні етичні поняття, закономірності й тенденції службових відносин, про моральні цінності, про моральні вимоги до форм, методів і стилю службової діяльності [13, с. 7] й одночасно - поведінку державних службовців відповідно 3 даними вимогами. Основними принципами адміністративної етики вважаються такі принципи: лояльність до влади, волі виборців, до опозиції та опонентів; добровільне і свідоме обмеження службовцями деяких своїх громадянських прав і свобод; гуманізм і соціальна справедливість; суворе дотримання букви і духу закону; сумлінне та відповідальне виконання службових обов'язків; патріотизм; інтернаціоналізм [7]. Таким чином, можна констатувати, що вченими до адміністративної етики включаються професійна етика державних службовців та посадових осіб місцевого самоврядування. Втім, хоча «державні службовці» та «посадові особи місцевого самоврядування» й охоплюються загальною категорією «публічні службовці», їхня служба регулюється окремими законодавчими актами, має свою специфіку, завдання, цілі, тому слід роз- різняти етичні норми поведінки вищезазначених осіб. Наприклад, такий принцип, як «воля виборців», не може бути віднесений до принципів професійної етики державних службовців. До того ж недоцільним убачається поміщення законодавцем норм етичної поведінки державних службовців і посадових осіб місцевого самоврядування в єдиний нормативно-правовий акт, яким $\epsilon$ Загальні правила етичної поведінки державних службовців та посадових осіб місцевого самоврядування, які затверджені Наказом Національного агентства України з питань державної служби 5 серпня 2016 року № 158 [1].

Ю.С. Даниленко зауважує, що в загальному розумінні етика поведінки державного службовця - це система етичних норм і принципів, установлений порядок дій, правил та взаємовідносин у державнослужбових відносинах, що базуються на ціннісних засадах державної служби та усвідомленні державним службовцем свого професійного призначення. Умовно етику поведінки державних службовців автор поділяє на два складники: а) теоретичний - комплекс набутих протягом життя етичних знань та моральних цінностей; б) практичний - установки до належної поведінки та застосування набутих знань у професійній діяльності [8, с. 70].

Погодимося з Н.В. Янюк, що пропонує етику поведінки державних службовців розглядати не лише як сукупність правил поведінки службовців між собою, а передусім їхній обов'язок проявляти високу культуру спілкування з іншими учасниками правовідносин, які не перебувають у державно-службових взаємовідносинах зі службовцем, тобто з іншими громадянами [21, с. 195].

Т.Е. Василевська формулює поняття «етика державної служби» та «етика державного службовця». Так, на думку вченої, етика державної служби - це інституційна етика, яка випливає з місії та філософії державної служби та презентує її цінності, професійно-етичні принципи, норми й механізми їхньої підтримки. Під етикою державного службовця розуміється основана на усвідомленні професійного призначення система професійноетичних цінностей, принципів і норм, які відображаються у свідомості державних 
службовців, орієнтують і регулюють їхні відносини, діяльність у сфері державної служби та механізмів підтримки професійно-етичного складника державної служби [4, с. 10]. Деякими авторами ці ж терміни розрізняються як «етика державної служби», отже, як інституціональна та організаційна етика та «етика державного службовця», що представляє професійно-етичні цінності та норми на рівні особи $[15$, с. 8$]$.

Найбільш вдалим здається визначення Ю.П. Битяка, який пропонує під етикою державного службовця розуміти ті моральні й правові (юридичні) вимоги, які ставляться до особи, що претендує на зайняття посади державного службовця та державного службовця в процесі виконання ним завдань і функцій держави, її органів [2, с. 175].

Етика державного службовця висуває специфічні вимоги до моральності державних службовців, які пов'язані з особливістю проходження державної служби. Професійна мораль державних службовців - це особливості моральної свідомості, поведінки, взаємовідносин з іншими особами, які зумовлені державно-службовою діяльністю.

Визначення морально-етичних засад поведінки державних службовців неможливо без урахування особливостей державної служби та місця державного службовця в суспільній діяльності.

С.М. Серьогін зауважує, що державна служба $\epsilon$ політичним, організаційноуправлінським та соціальним інститутом держави, що забезпечує комплекс відносин між окремими громадянами, громадянами та їхніми спільнотами та між державами, використовуючи владні ресурси $[17$, с. 64]. На думку вченого [17, с. 62], суспільна роль державної служби полягає у виконанні завдань держави та реалізації її функцій.

Завдання та функції держави, які виконує державна служба, полягають у забезпеченні суверенітету, незалежності, розвитку України як демократичної, соціальної, правової держави, де людина, ії життя і здоров'я, честь і гідність, недоторканність і безпека визнаються найвищою соціальною цінністю, а права і свободи людини та їх гарантії визначають зміст і спрямованість діяльності держави. Утвердження й забезпечення прав і свобод людини $\epsilon$ головним обов'язком держави (ст. 3 Конституції України).

Науковці розглядають державного службовця з різних аспектів: як фізичну особу, громадянина України, який має відповідну освіту і професійну підготовку та пройшов у встановленому порядку конкурсний відбір (В. Малиновський); як будьякий суб'єкт права - громадянин України, що має конституційно закріплені права (О. Оболенський); завжди розглядається у відносинах між владою і суспільством (С. Серьогін); завжди повинен удосконалювати свою професійну компетентність (Н. Липовська) тощо [6, с. 6]. Т.Ю. Витко стверджує, що державні службовці $\epsilon$ своєрідним зв'язком між державою та громадянами, держава та її службовці повинні бути своєрідним гарантом надання якісних послуг громадянам відповідно до чинного законодавства, захищати їх від свавілля недержавних структур тощо [5, с. 41]. Виконання державними службовцями завдань і функцій держави на професійній основі має гарантувати сталість і стабільність державно-службових відносин, добробут суспільства й силу держави, бездоганність та ефективність управлінської діяльності, її незалежність від можливих політичних змін [9, с. 38, 39].

Так, державні службовці займають специфічне місце в суспільстві, оскільки вони реалізують державну управлінську діяльність і державно-владні повноваження; в професійній діяльності державних службовців складаються особливі відносини; відносини між державними службовцями і громадянами вибудовуються на засадах служіння державного апарату народові, його інтересам; для побудови стосунків усередині професійної групи державних службовців кардинальне значення має принцип ієрархії. Підвищені моральні вимоги в державному управлінні зумовлені розпорядженням великими матеріальними цінностями, людськими ресурсами; безпосереднім впливом на життя конкретних людей; існуванням ризику, непередбаченості в діяльності, сполученням формально-процедурних регламентацій діяльності з можливістю прийняття вольових суб'єктивних рішень, імовірним 
творчим характером праці. Ці чинники призводять до виникнення особливих етичних проблем професійного життя державних службовців (проблеми дотримання державної таємниці, протидії корупційним діянням, збереження конфіденційної інформації громадян, політичної неупередженості, обмеження частини політичних, природних їхніх прав тощо) [15, с. 7].

Автори, які розглядають комунікативні компетентності державного службовця, специфіку праці цих службовців убачають у тому, що вони виконують роботу, яка виражається в обґрунтуванні цілей і напрямів суспільного розвитку; займають посади в органах державної влади та представляють їх, а також володіють особливим предметом праці - інформацією, яка водночас виступає засобом державного нагляду і надання адміністративних послуг [11, с. 4].

Крім того, під час розгляду особливостей професійної етики державних службовців слід мати на увазі, що існують особливості діяльності державних службовців у залежності від їх видів. Відповідно до видових і родових класифікацій, представлених у науковій літературі, можна виділити етичні стандарти поведінки в тій чи іншій галузі проходження державної служби.

Державна служба поділяється залежно від вибраних критеріїв класифікації на різні види. Зокрема, на підставі конституційного принципу поділу влади виокремлюється державна служба в законодавчому органі, в органах виконавчої влади, в органах судочинства. Однак погодимося з ученими, які вважають, що така класифікація не охоплює всієї багатогранності державної служби, оскільки не враховує, наприклад, особливостей служби в органах прокуратури, Адміністрації Президента України, Національному банку України, оскільки названі установи формально не належать до жодної із трьох гілок влади.

Більш узагальненою класифікацією державної служби є поділ на роди, до яких належать військова, управлінська та спеціалізована служба. у межах військової служби виділяються такі види: армійська, прикордонна служба, служба в органах внутрішніх справ, служба в органах безпеки і т.д. Щодо управлінської служби, то йдеться про проходження державної служби у сфері управління економічними процесами, управління у фінансовобюджетній сфері, управління власністю, управління освітою і культурою, управління соціальною сферою тощо. До спеціалізованої державної служби належать: судова, кримінально-виконавча, митна, прокурорська, радіаційна, метрологічна, екологічна, санітарно-епідеміологічна, служба з надзвичайних ситуацій тощо [9, с. 137].

Н.С. Тимченко виявила специфіку діяльності службових осіб митних органів та визначила поняття «професійна етика службових осіб митних органів». Під професійною етикою службових осіб митних органів розуміється галузь етичної науки, що вивчає як застосування загальних норм моралі, моральності в діяльності та повсякденній поведінці службових осіб митних органів, так і особливих норм професійної моралі, що виникають та втілюються тільки в даній професійній групі (підгрупах) [18]. Коментуючи вищезазначене поняття, варто було 6 уточнити, на яку категорію працівників митних органів поширюється поняття «професійна етика», тобто що автор розуміє під терміном «службова особа митних органів», оскільки, по-перше, Митний кодекс України регулює правовий статус посадових осіб митних органів, по-друге, в митних органах можуть працювати особи за трудовим договором, які не $\epsilon$ посадовими особами та на яких повною мірою поширюється трудове законодавство.

А. Музиченко визначає поняття «суддівська етика» як стандарти професійної поведінки суддів, що характеризуються наявністю підвищених моральних вимог, зумовлених високою відповідальністю їхньої праці [14, с. 85].

Стосовно професійної етики працівників Державної податкової служби (ДПС) науковці зазначають, що дії та рішення податківців зачіпають права та інтереси громадян, тому вони повинні відповідати принципам і нормам моралі, охороні авторитету державної влади та ії представників. Виконання державних обов'язків потребує від представників влади розвинутого почуття відповідальності за свої рішення, дії. Процес стягування податків 
не $є$ завжди добровільним, тому співробітники ДПС виконують комунікативні, організаторські, виховні та інші функції, реалізація яких вимагає найвищого напруження психіки, зібраності у спілкуванні з платником податків. Їхні дії та рішення повинні відповідати закону [3].

Висновки. 3 урахуванням викладеного слід зробити певні висновки. Державні службовці мають особливе суспільне призначення, цілі, завдання, які зумовлені особливостями їхньої професійної діяльності. Виконуючи завдання і функції держави, державні службовці потенційно мають конфлікти (у тому числі конфлікт інтересів), складні ситуації, корупційні ризики, що вимагає наявності не лише професійних (ділових), психологічних якостей, освітнього рівня, а й моральних якостей. Під час виконання своїх посадових обов'язків державні службовці мають усвідомлювати, що вони зобов'язані вірно служити народові України й гідно нести звання державного службовця. Під професійною етикою державних службовців слід розуміти систему моральних і правових вимог, принципів, яких повинні дотримуватися державні службовці під час виконання завдань і функцій держави на професійній основі.

Професійна етика окремих груп державних службовців відображує видові та родові особливості державної служби, що має бути враховано у відповідних нормативно закріплених правилах етичної поведінки державного службовця та під час розроблення теоретичних положень етики професійних груп державних службовців.

\section{ЛITEPATУPA:}

1. Загальні правила етичної поведінки державних службовців та посадових осіб місцевого самоврядування : затв. Наказом Національного агентства України з питань державної служби 05 серпня 2016 р. № 158. Офіційний вісник України. 2016. № 74. Ст. 2493.

2. Битяк Ю.П. Державна служба в Україні: організаційно-правові засади : монографія. Харків : Право, 2005. 304 с.

3. Бралатан В.П., Гуцаленко І.В., Здирко Н.Г. Професійна етика : навч. посібник Київ : Центр учбової літератури, 2011. 251 с.

4. Василевська Т.Е. Етика державних службовців і запобігання конфлікту інтересів : навч.- метод. матеріали / уклад. О.М. Руденко. Київ : НАДУ, 2013. 76 с.

5. Витко Т.Ю. Державний службовець в умовах реформування державного управління в Україні. Аспекти публічного правління. 2018. Т. 6. № 3. С. 39-47.

6. Витко Т.Ю. Службова кар'єра державних службовців в Україні : навч.-метод. посіб. Івано-Франківськ : ІФОЦППК, 2016. 56 с.

7. Войтенко А.Б., Якобчук В.П., Пугачова Н.С. Професійна етика державного службовця в контексті ефективності публічного управління. Державне управління: вдосконалення та розвиток. URL: http://www.dy.nayka.com.ua/pdf/2_2020/38.pdf. (дата звернення: 10.07.2021).

8. Даниленко Ю.С. Стан правового регулювання етики поведінки державних службовців в Україні. Вісник Чернівецького факультету : зб. наук. праць НУ «ОЮА». Чернівці, 2015. № 4. С. 66-78.

9. Державна служба : підручник : у 2 т. / Нац. акад. держ. упр. при Президентові України ; редкол. : Ю.В. Ковбасюк (голова) та ін. Київ ; Одеса : НАДУ, 2012. Т. 1. 372 с.

10. Етика: навч. посіб. / В.О. Лозовой та ін. ; за ред. проф. В.О. Лозового. Київ : Юрінком Iнтер, 2007. 224 c.

11. Комунікативна компетентність державних службовців як елемент модернізації системи державної служби / Івано-Франківський центр науки, інновацій та інформатизації. Івано-Франківськ, 2012. 154 с.

12. Котович Г.В. Етика державних службовців та посадових осіб місцевого самоврядування. Публічне управління та адміністрування : автореф. роботи магістра публ. упр. : Спец.: 281. Миколаїв, 2019. URL: https://krs.chmnu.edu.ua/jspui/bitstream/123456789 (дата звернення: 10.07.2021).

13. Мельников В. П. Державна служба в Україні: Історичний досвід. Київ : РАГС, 2010. 389 c. 
14. Музиченко А. Порушення правил суддівської етики - підстава дисциплінарної відповідальності судді: межі застосування. Вісник Київського національного університету імені Тараса Шевченка. 2011. № 87. С. 84-87.

15. Норми та стандарти поведінки державних службовців: методичні матеріали / Харківська обл. держ. адміністрація. Харків, 2020. URL: https://kharkivoda.gov.ua/content/ documents/1044/104311/Attaches/etichna_povedinka.pdf. (дата звернення: 11.07.2021).

16. Професійна етика. Норми професійних ділових відносин : навч. матеріали онлайн. URL: http://pidruchniki.com/10280405/menedzhment/profesiyna_etika_normi_profes iynih_ dilovih_vidnosin (дата звернення: 11.07.2021).

17. Серьогін С.М. Мета, завдання та функції державної служби. Аспекти публічного управління. 2013. № 1 (1). Вересень. С. 58-65.

18. Тимченко Н.С. Формування професійно-етичних якостей майбутніх службовців-митників : автореф. дис. ... на здобуття наукового ступеня канд. пед. наук : 13.00 .04 ; Центр. ін-т післядиплом. пед. освіти АПН України. Київ, 2003. 20 с.

19. Требенець Н.I. Публічний виступ: «Професійна етика публічного службовця та запобігання конфлікту інтересів». Сайт спільноти кращих державних службовців. URL: http://www.kds.org.ua/presentation/trebenets-ni-publichnij-vistup-profesijnaetikapublichnogo-sluzhbovtsya-ta-zapobiganny (дата звернення: 12.07.2021).

20. Чайка Г.Л. Культура ділового спілкування менеджера : навч. посіб. Київ : Знання, 2005. $442 \mathrm{c}$.

21. Янюк Н.В. Актуальні проблеми у регулюванні питань професійної етики публічних службовців. Вісник Львівського університету. Серія: Юридична. Львів, 2014. Вип. 59. С. 194-199.

22. Яремин I.I. Аспекти етичних правил поведінки публічних службовців : навч.-метод. посіб. Івано-Франківськ : ІФОЦППК, 2016. 68 с. 